\title{
Innovative Development of Higher Education
}

\author{
Irina Vladimirovna Khristoforova \\ Julia Sergeevna Popova \\ Dina Rafikovna Makeeva \\ Elena Dmitrievna Shtrafina \\ Tatiana Nikolaevna Arkhipova
}

\begin{abstract}
Moscow Region State Budgetary Educational Institution of Higher Vocational Training «Finance and Technology Academy»
\end{abstract} City of Korolev, Russia, Building 42, Gagarina Street, Korolev, Moscow Region 141070

Doi:10.5901/mjss.2015.v6n4p594

Abstract

The article considers the essence of innovation in higher education and the integration of educational, scientific and industrial scope. Disclosed forms of innovation in higher education, as well as their role in the interaction of education, science and business. Defined forms of cooperation between education, science and business. Review the modalities of cooperation between education and business in the examples of financial and technological academy city of Korolev, Moscow region. Were revealed directions of innovation developing higher education.And also drawn conclusions on the matter.

Keywords: higher education, small innovative enterprises, science and innovative business.

\section{Introduction}

Innovation scope today is an important development trend of the economy of developed countries. But, unfortunately, the transition economy of Russia on a path of innovative development, the process is quite long and difficult (web portal, 2014). To start must form the basis of the innovation economy, and as a result, appropriate to spend modernization of higher education (Oyuuntsetse \& Davaanyam, 2007).

The world experience shows that "...in advanced economies such as the European Union, knowledge, called R \& d, innovation and education, acted as a key strength of productivity growth. Knowledge is a key factor, with which Europe can ensure competitiveness in the global market, where others compete with cheap labour as the main resource. Emphasis on knowledge, education and innovation in our revised Lisbon strategy will give people the opportunity to climb the ladder of performance and ensures that throughout our capacity to grow rapidly; while "education" will reward students "human capital and skills in a dynamic knowledge-based economy" (Ushakov \& Yeh, 2013; Milner, 2013). From this it follows that at the present time, the dynamic development of the economy of the European Union is associated with the concepts of "knowledge", "innovation" and "education".(Aldoshin, S.M. et al , 2013).

Adopted in Russia at Federal and regional level strategic documents also clearly held the idea that innovation in various fields and the implementation of innovative potential of the regions of our country will overcome the Russian economy's dependence on exports of raw materials and to create a new type of economy based on information and knowledge. Thus, the government has stated its position: the most important direction of innovative development is the change of Russia's human potential, which, of course, is not limited to education, and includes the penetration of innovations in healthcare, physical culture and sport, culture, etc. But it is the education and above all the Supreme, is the basis for the formation of personnel for implementation of tasks of innovative development (Kryukova et al., 2013; llina et al., 2014).

To improve the innovative development of higher education in Russia, just need to develop scientific activity in educational institutions of higher education, to create innovation networks, ending with close interlinkage of scientific knowledge and innovative commercial product (Milner, 2013).

Thus, investigation of the potential of innovative development of higher education and generalization of the experience of higher education institutions is one of the most relevant topics. (Startseva et al., 2013) 


\section{Research Methodology the Innovative Integration of Education, Science and Business}

\subsection{General Approaches to research methods}

This article is a review and constructed on the basis content analysis of secondary data - opinions national and foreign experts in the field of innovation educational institutions of higher education, presented in various professional publications, collections of scientific conferences, monographs, in the media, including Internet. (Maloletko et al., 2015)

In addition, we used the method of logical analysis of a particular educational institution Moscow Region State Budgetary Educational Institution of Higher Vocational Training "Finance and Technology Academy", Korolev, Moscow region.

The essence of integration of educational, scientific and industrial scope expressed in their interrelated activity with a common ultimate goal. The main objective higher education is the dissemination of knowledge, including scientific, etc., their accumulation and transfer to the next generationsand also development in people the ability to use their own knowledge in life and in work (Oyuuntsetse \& Davaanyam, 2007).

Innovation in education is quite diverse: it and organizational and managerial innovations, and the creation of new conditions or new products focused on both internal and external use (with the possibility of further capitalization). the staff.

The area of diffusion of innovation in education can be focused on: training, education, management, training of

Innovations in education are offered to understand new methods of teaching, new ways of organizing activities, innovations in the organization of educational content integration (interdisciplinary) programs, methods of evaluation of educational results.

Innovations in upbringing are offered to understand system aimed at creating a social and cultural environment conducive to the development as a modern, forward thinking individual, and contributing to the successful implementation of the educational program, mastering the inherent cultural and professional competences.

Innovation in management is aimed at attracting members of the society to the management of educational institutions, as well as the creation of the original scheme of organization of the management and economic activities of educational organizations.

Innovation in the training and retraining of education is focused on the involvement of practicing teachers, new programs of retraining, aimed at changing the requirements to the quality of education. (Kryukova et al., 2015)

\subsection{Forms of integration of education, science and business}

Functionality of innovation in education implies the creation:

- Innovative educational environment;

- Innovative products (business innovation);

- Organizational and administrative innovations.

If the first and the third direction have found greater development and reflects reforms in higher education, the business innovation in education a relatively new phenomenon for the Russian economy and, unfortunately, weakly developed. However, the state and the higher school attributed to innovative business bold enough hope.

As already noted, the efficiency of the final result will be achieved, taking into account the interests of education, science and business (Popova, 2014). The process of improving this integration occurs by means the needs of society, presented in Figure 1 (Oyuuntsetse \& Davaanyam, 2007).

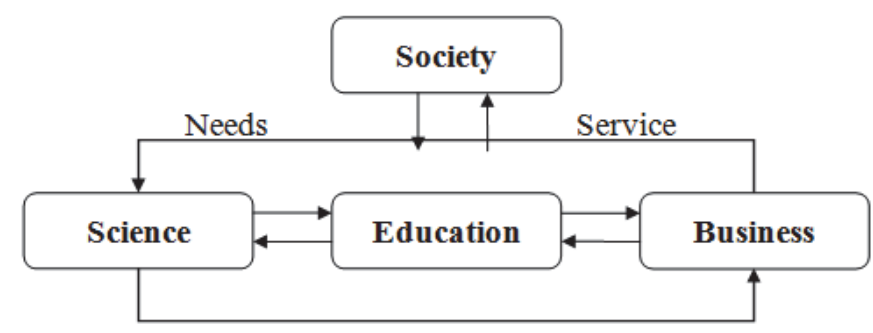

Figure 1. Integration of science, education, business and society 
According to Federal Law \# 217-FZ contemporary educational institutionsof higher education represented as economic enterprises, directed to making a profit. And the order of creation and registration - the same as for ordinary economic societies (Federal Law of 02.08.2009 № 217-FZ).

In the course of the activity small innovative enterprises evolve through different phases development of innovation and economic activity. Establishment and functioning of small innovative enterprises by educational institutions of higher education not only favors the development of the educational institution, but for the whole system of higher education. (Ivanov et al., 2014) This can be seen in the improvement of material and technical base of educational institutions and the development of scientific projects within it, rationalize the educational process due to additional practical training for students and funding for student internship opportunities in other regions, or even countries. Benefits of creating an innovative business for the education sector include: promotion of scientific activity, the implementation of innovative projects of scientific institution, obtaining practical knowledge by students an extra source of funding for an educational institution of higher education, improving the competitiveness of students in the labor market and improving the image of the organization and its development (Alexandrova \& Badaev, 2010, Arkhipova, 2013).

\subsection{Small innovative companies is the basis of integration.}

Thus, the direct link to the integration of science and business may be small innovative businesses contributing to the conclusion of an innovative product on the market and thus income. The organization of such enterprises is the desire of its founders to become self-employed, as well as meet with their own interests and needs.

It turns out that small innovative companies take on the role of mediator between industry and academia. It is known that in countries with high-tech economy the most dynamic sector of the innovative economy form it is small innovative enterprises, by which he is able to respond quickly to market needs. Usually when developing new products and technologies it is small businesses take risks in their assimilation and excretion on the market. As a consequence of the risk nature of the activity composition of small enterprises is variable: some disappear, new ones appear.

The study of domestic and foreign experience of cooperation between scientific organizations, education, including in the face of small innovative enterprises and business shows that there are several forms of cooperation:

1. Cooperation between independent institutions of science, education and business on the basis of the contract;

2. Cooperation between institutions of science, education and business two-way;

3. Creating a unified set of institutions of science, education, business.

The choice of forms of cooperation is determined by the priorities in the activities of educational organizations: academic training, research, practical training, etc.

Under these conditions, at the forefront of innovation, involving institutional change in higher education institutions, aimed at expanding the contribution of the education system in the socio-economic sphere of society.

Guide the innovation process in higher education can serve as criteria for support of universities used in the priority national project "Education":

- the involvement in regional development programmes;

- the innovative structure, integrated into the economic space of the region;

- the participation in large-scale projects;

- the application of modern educational and management technologies;

- the international activities.

In addition, it is envisaged to strengthen the role of economic methods of management higher education, which will generate economic relations educational institution of higher education as a business entity in the market economy at all levels between the university and the state; between universities, businesses and research organizations; between the university and students. Thus, the conditions can be created for the conversion of Russian educational institutions of higher education in the integration centers, which should be focused on the development and introduction of new technologies in the educational activity, and in the research and innovation with elements of commercialization (figure 2) (Kuleshova, 2013;Kaurova et al., 2013). 


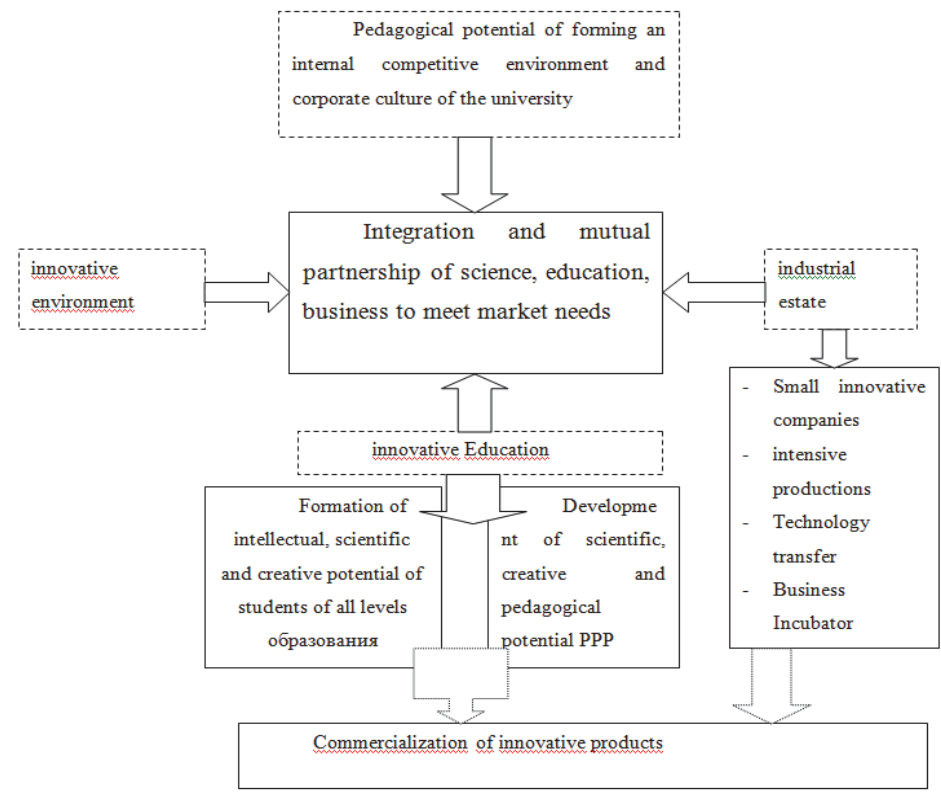

Figure 2. Model of interaction between science, education, business

\subsection{Directions of development of innovative activity of students}

Formation of the organization of higher education innovation base, the main link which should be small innovative enterprises (SIE), a beneficial influence on the activities of the educational organization, provides an opportunity to prepare business oriented and creative specialists in demand in the current context of technological modernization of the economy. But the effective work of the innovative organization offering a positive effect on the production of an innovative product is possible only if the system organization in the field of education integrated development of innovative and research activity (Vdovenko, 2012).

This activity provides a comprehensive development of the organization IN the way of setting and subsequent implementation of the following new tasks:

- the training of graduates of the new qualification and business levels corresponding to the modern requirements of the labour market;

- the training and retraining of teaching staff focused on competence-based approach and the foundations of estimated means students;

- the promotion and formation within the educational process of the source of innovative ideas.

Theoretical and applied research of this problem a cause for of distinguishing three main directions of its productive solutions, promotes the formation and development of the students' innovative potential, and as a result the development of innovative business. The first is related to the development and implementation of high school preparation into disciplines of innovation orientation, the second - with the elaboration and development of innovation in a meaningful term (component) vocational training of experts, and the third - with the active introduction to the educational process integration technologies on student learning of practical basis (Dziov, 2011).

\section{The Results of Innovation Processes in the Financial and Technological Academy}

\subsection{Continuing education in Finance and Technology Academy}

The revealed four directions of innovative development of higher for education that facilitates the preparation of forwardthinking and acting experts, innovative business development in various forms are reflected in the activity of Financial Technology Academy of Korolev, Moscow region (Oyuuntsetse \& Davaanyam, 2007).

Feasibility of introducing disciplines in the educational process of innovation orientation determined the need for theoretical and practical training based innovative thinking and acting specialists able to successfully solve perspective 
tasks, related to innovation and technological development of our country (Alexandrova S.Y.\& Badaev M.M., 2010).

Educational process by Financial Technology Academy is focused not only on the transfer of knowledge, which will eventually retires, but also to master the basic skills to enable future expert to acquire knowledge throughout life. An important role is played here by succession and continuity of education.

In the structure of Financial and Technology Academy comprises two educational institutions of secondary professional education: College of Space Engineering and Technology and the Technical school of Technology and Design. In this connection continuity implemented programs of secondary professional and higher education at various levels: bachelor and master. In several areas may completion of education in graduate school (Oyuuntsetse \& Davaanyam, 2007).

Employees of Executive bodies, ministries and departments of the Moscow region, heads and specialists of the institutions, enterprises and organizations, area residents, the unemployed, registered at the employment Center can improve their skills and professional retraining short-term seminars and continuing education programmes for different categories of students implemented the FTA. For managers of commercial enterprises organize activities aimed at solving business problems: conferences, workshops, strategic sessions with the participation of leading practitioners. The Academy develops and conducts seminars and workshops on the applications of interested persons with the subsequent publication of instructional materials.

\subsection{Constant updating of educational programs is the basis of the development of education.}

The second direction of a sustainable solution to problem, related to the development innovative potential students has to do with elaboration of innovative content taught academic disciplines (Hristoforova et al., 2011).

The expediency dictated by the dynamics in this modern and professional life. Accordingly this dynamics, should change and adjusted the content of academic disciplines.

This is accomplished in the integration of fundamental science, educational process and production. Together with the city-forming enterprises JSC RSC "Energia", JSC Corporation "Tactical Missile Armament", Research Institute of Cosmic Systems named. AA Maximova, FSUE TsNIIMash Academy conducts scientific and educational activities in the area of corporate finance, computer modeling and design, system of quality, of introduction of information systems in all areas of production.

In order to bring the educational process to the real conditions of modern production and use results of scientific research in the educational process, in the leading scientific and industrial enterprises in the region created a basic chair, where teachers are leading specialists with extensive practical experience. Students of senior courses not only get an idea about the organization of economic, technological and other processes on specific companies, but also on practical lessons deal with specific problems. At the annual student conferences students on Foundation courses are interesting reports of practical importance. They have the interest and drafting the reports. Additionally, students write and defend their thesis work at the company on practical topics. Many students on Foundation courses, have the opportunity along with training to work in these enterprises. Thus, upon graduation, the students have not only the representation of processes in a particular enterprise, but also practical skills (Shtrafina, 2011).

\subsection{The maximum approach to production.}

Training on basic departments allows you to bring the learning to practical activities, students acquire already at the stage of learning practical skills and confidence that they will be useful in their future career, and employers to know better future workers, to choose the best of them and focus their attention on a specific result.

Actualize also to change the contents academic disciplines taught modern teaching concepts such as a studentcentered learning, innovative teaching, distance learning competentive training. It is very important the flexibility of the teacher, his knowledge and skills, the ability to learn throughout his career. How competent and creative teacher, how deeply he knows the problems of disciplines and is able to correctly construct the learning process, so students will be able to enrich themselves with knowledge in a particular subject area and to apply them in practical work (Hristoforova et al., 2011, Maksimtsev et al., 2007).

Educational plans envisage design development, trainings, business games, traineeship and practice in manufacture, scientific research organizations.

The third direction of the optimal solution to the problem of innovation capacity development is the introduction in the educational process of integration of educational technology with business processes.

Feasibility of this direction dictated by the dynamic development in all spheres of social life, including those 
education. In this regard, modern educational practice a lot of attention is paid to information and communication technologies to innovative learning. Scientific and educational communities, business incubators, etc... Example is the network of educational centers:

- "Priorities directions of materials technology in space systems" together with public corporation "Komposit";

- " "Innovation technologies in complex technological systems" together with Public corporation "Komposit";

- "Information technologies" together with public corporation "SPA of measurementtechnology";

- "Space innovation" togetherwith Research Institute of space systems named after A.A.Maksimov;

- "Engineering systems managing"together with public corporation "Tactical Rocket Armament";

- "Eco resources" together with non-commercial partnership "UnicumService".

The fourth direction is based on Federal law No. 217-FZ. Therefore, a Financial and technology Academy were organized small innovative enterprises. They are created for practical implementation in the production of the results of intellectual activity of teachers, postgraduates and students of the Academy.

In a globalized economy, and development of international contacts, international integration into the international educational community, to achieve an optimum level of performance of the educational and research activities (Milner, 2013).

Currently Financial and Technological Academy implements a cooperation agreement with Russian and foreign companies, including:

- Federal agency "Rossotrudnichestvo";

- Academy of Finance (Kazakhstan);

- New Education University (Bulgaria);

- Kyrgyz Economic University named. M Ryskulbekov (Kyrgyzstan);

- SKOLA Group (England);

- Khmelnitsky National University (Ukraine);

- Vitebsk State Technological University (Belarus);

- University EuroSwiss (Switzerland);

- University of ModenaRegio Emilia (Italy);

- University of Fairmont, West Virginia (USA), etc.

\section{Discussion}

Thus, the priorities for Financial and technological Academy in the field of education, science and innovation, staffing of these processes are: the formation of a training system capable of innovation; the creation of a system of vocational education, providing training for development of innovative economy. These priorities are essentially coincide with the priorities set before a European Union policy documents, this is an indication that these tasks fit into the process of the globalization of science and education. Also, these priorities reflect the basic state policy in the field of development education: Financial and technology Academy is a regional institution of higher education of the Moscow region, has been training for enterprises of the region, (Korolev), actively rassviet cooperation with the city-forming enterprises.

Thus, sustainable innovative development of the country, the accumulation and implementation of innovative potential is impossible without the modernization of higher education, which is the basis for the development of human potential, a base for innovation and research, and which, thereby, is a factor of innovative development of Russia.

The priorities of Russia's development are determined by what is happening in the modern world of globalization and the need to increase competitiveness in various industries and areas of life, "fit" in the emerging and developing economic system. The logic of Russia's transition to a certain extent, the same processes in the countries of the European Union, and the development priorities in the guidelines can be considered similar. Therefore, the process of modernization of economy and social sphere in our country must meet global trends and certain standards, some of which are already in place in other countries. Therefore there is a need for the development of new, knowledge-based, innovative economy and social sphere, the implementation of innovative potential of our country, which in many ways has yet to form.

The formation of an innovative economy is possible only in close connection with the modernization of higher education, because education, science and business are the leading factors of innovative development. Priorities for the development of education defined in the strategic documents, suggests that this area directly affects the development of human potential, and hence on the development of science and innovation.

The organization of higher education is simply necessary to develop innovative and research activities, 
establishing interdisciplinary links that can bring a new level of quality education (Veselovsky et al., 2007; Veselovsky \& Semenyak, 2007).

At the heart of this area just need to exchange knowledge between science and industry is carried out, including through the formation of basic departments and small innovative enterprises contribute to the conclusion of an innovative product on the market and thereby generate income. The organization of such enterprises is the desire of its founders to become self-employed, as well as meet with their own interests and needs (Vdovenko, 2012).

When preparing the organization of higher education graduates at all levels of training should take into account conditions and evaluation criteria established in connection with the current technological upgrading Russian enterprises that require a new quality of preparation of bachelors and masters (specialists)demanded by enterprises. Orientation of new personnel should be directed to work with the technologies of tomorrow. Such training cannot be carried out without the direct involvement of faculty and graduate students in advanced research, without practical personal involvement of students in their respective works.

These tasks cannot be accomplished without major development assessment of relevant competencies established by the FGES. Organization of higher education needs in the short term to increase research capacity in various areas of academic activities of departments, providing the position of "leading sites of scientific and innovative research work of the existing economy. Organization of higher education should act as a generator of ideas and developments, and as a member of scientific expertise solutions for enterprises and government.

As research activities in many educational organizations behind academic science, innovation is generated by the actual results achieved, that is still beyond the boundaries of planning and development.

Innovative development of higher education, contributing to the preparation of forward-thinking and acting experts should be conducted in three directions:

- Development and implementation of an educational organization into higher education innovation disciplines demanded by society;

- Introducing innovative adjustments to the content taught in academic disciplines;

- Development and implementation in the educational process student learning of innovative technologies.

\section{Conclusions}

Thus, classification of institutions of higher education, innovation, research and development work must be considered:

1. A necessary component to ensure the required quality of the educational process, including:

- $\quad$ the participation of the organization in the preparation of professional standards;

- the teaching of most subjects of the curriculum using project (modular and simulation) learning technologies;

- the regular information about changes of state educational standards;

- $\quad$ the part of the faculty organization In R \& d;

- the organization of practical training of students in scientific institutions or enterprises, forming the modern technological environment or with tools;

- the provision of internship opportunities for students in other organizations;

- the public awareness through the media about the results of scientific and research activities of the organization;

2. Additional extra-budgetary resources through the activities of Sies, including:

- the involvement of foreign partners in the scientific and research work (contracts);

- $\quad$ the involvement of business angels;

- the real implementation of scientific ideas.

This will give a positive result in the educational process and the improvement of innovation and research in the organization of higher education.

Effective organization and promotion of scientific, research and innovative activities of the organization of higher education is largely determined by the creation of small innovative enterprises and their actual activities, including the production of high-tech, innovative products.

\section{References}

Aldoshin, S.M., Berzigiyarov, P.K., Bouznik, V.M., Ciganov, D.I., (2013). Supporter Program of innovative activity by the Russian Academy of Sciences. Bulletin of the Russian Academy of Sciences. Publisher: Academic Scientific Publishing, printing and 
production and Bookselling Center RAS Publishing House "Nauka" (Moscow), \# 7, p: 587.

Alexandrova, S.Y., Badaev, M.M., (2010). Use of foreign experience in shaping the innovation system of higher education in the Russian Federation: Monograph. M.: IMPE them. Griboyedov, p: 5.

Arkhipova, T.N., (2013). Topical application of innovative methods in training system fashion and beauty industry. Bulletin of the Association of Universities for Tourism and Service. \# 1. pp: 26-32.

Dziov, A.R., (2011). Contents of higher education in the transition to innovative development: Modern problems of science and education, \# 3, p: 26.

Federal Law of 02.08.2009 \# 217-FZ "On Amendments to Certain Legislative Acts of the Russian Federation on the establishment of budget scientific and educational institutions, business entities with a view to practical application (implementation) of the results of intellectual activity."

Hristoforova, I.V., Kolgushkina, A.V., Makeeva D.R., (2011). Higher Professional Education of the Russian Federation: key trends and issues of development. Electronic Journal "service in Russia and abroad», \# 3 (18), URL Date Views 20.06.2014 rguts.ru/elektronic journal. pdf.

llina, I.Y., Belotelova, N.P., Danilina, E.I., Novikova, D.M., Pochinok, N.B. (2014) «Professorate unemployment» in the modern Russia. Asian Social Science, 10 (24), 217-223

Ivanov, V.V., Lipkind, A.N.,Markusova, V.A., (2014). Publication activity and scientific cooperation of universities and RAS. Bulletin of the Russian Academy of Sciences. Publisher: Academic Scientific Publishing, printing and production and Bookselling Center RAS Publishing House "Nauka" (Moscow), \# 1, p: 32.

Kryukova E.M., Vetrova E.A., Maloletko A.N., Kaurova O.V., Dusenko S.V. (2015) Social-Economic Problems of Russian Mono-Towns. Asian Social Science, 11(1), 258-267

Kryukova, E. M., Makeeva, D.R. (2013) Analysis of World and Russian Best Practices of Strategic Development of Mono-Towns.World Applied Sciences Journal 27 (Education, Law, Economics, Language and Communication): 167-171, 2013 ISSN 1818-4952 @ IDOSI Publications, 2013 DOI: 10.5829/idosi.wasj.2013.27.elelc.35 (http://www.idosi.org/wasj/wasj27(elelc)13/35.pdf)

Kryukova, E. M., Makeeva, D.R., Atamanova, M.A., Shadskaja, I.G. (2013) Financial mechanism of housing and utilities infrastructure. Life Science Journal (Life Sci J), Volume 10 - Number 4 (Cumulated No. 35), 25, 2013. life1004 (http://www.lifesciencesite.com /lsj/life1004/099_21206life1004_790_794.pdf)

Kuleshova, G.I., (2013). Development of innovation centers and the transformation of the urban environment as complements resources. Bulletin of the Russian Academy of Sciences. Publisher: Academic Scientific Publishing, printing and production and Bookselling Center RAS Publishing House "Nauka" (Moscow), \# 7, p: 626.

Maloletko, A.N., Kaurova, O.V., Kryukova, E.M., Pochinok, N.B., Gladko, E.A. (2015) Analysis of key indicators of tourism industry in Russia. Modern Applied Science. Vol. 9 (3), pp. 25-33

Milner, B.Z., (2013). "The global economy and lifestyles on the threshold of a new era." Bulletin of the Russian Academy of Sciences. Publisher: Academic Scientific Publishing, printing and production and Bookselling Center RAS Publishing House "Nauka" (Moscow), \# 4, p: 362.

Oyuuntsetse, L., Davaanyam, S., (2007). Innovative directions integration of science education-industry. Proceedings of ISEA, \# 1. pp: 33-37.

Popova, J.S., (2014) Small innovative enterprises as the main link building an innovative bases for higher education. Collection of International extramural scientific and practical conference "Prospects and paths of cooperation between science and business in modern society" Moscow.

Shtrafina, E.D., (2011). The modular structure of academic disciplines as an innovative component of the educational activities of the university. Collection of Articles III annual conference of graduate students KIUES "Innovative aspects of the socio-economic development of the region", KIUES, Korolev.

Startseva ,T.E., Khristoforova, I.V., Trishkina, T.V. (2013) Stimulate the creative activity of teachers of FTA // Sat. proceedings of the first International scientific-practical Internet-conference "FTA" "Modern educational technologies used in the full-time, part-time and secondary education, Korolev/

Ushakov, D., Yeh, S.P., (2013). Prospects of innovative economies development in the dynamics of globalization and technological progress. Actual Problems of Economics,\#141,\# 3, pp: 47-53.

Vdovenko, A.A., (2012). Small business in the development of the innovation environment. Bulletin of Yaroslavl state University. P.G. Demidov. Humanities", \# 1. pp: 75-81.

Veselovsky, M.E., Semenyak, O.V. , (2007). Development of the market of educational services of higher education in the formation of a unified educational space. J. Bulletin of SSSEU, \# 17.

Veselovsky, M.E., Semenyak, O.V., Korolev, V.A. , (2007). Priority areas for improving the regulation of the market of educational services of higher education in the Russian Federation J. Regional economy: theory and practice, \# 4. 